\title{
Customers as Volunteers? E-Customer Citizenship Behavior and Its Antecedents
}

\author{
Gokiladevi Ponnusamy, Jessica Sze Yin HO* \\ Sunway University Business School, Malaysia \\ jessicah@sunway.edu.my*
}

\begin{abstract}
The low barriers to enter into the e-marketplace have inevitably intensified the competition among e-retailers. Online retailers are struggling to build a sustainable business model that ensures customers' continuing commitment to their businesses. This study addresses the challenges faced by eretailers in terms of examining website services and functionalities that would consequently lead to eloyalty among customers. Empirical findings, based on 385 online apparel shoppers, have shown that extending customers' voluntary behavior (customer citizenship behavior) that can be cultivated upon gaining customers' satisfaction and loyalty provide leads to a better future for e-retailer's sustainability. This study examines the applicability of expectancy-disconfirmation theory and social exchange theory in the virtual world.
\end{abstract}

Keywords: Website Quality, E-Loyalty, E-Customer Citizenship Behavior, E-retailing

\section{Introduction}

The year of 2013 showed many elements of a perfect storm with the slowdown in emerging markets and ongoing weak consumer confidence in developed global markets. Despite these circumstances, online shopping is proved unstoppable as the sales of e-commerce rose to USD \$ 693 billion dollars worldwide in 2013 (Euromonitor International, 2014). Reasons, such as product selection and variety, availability of information, cost saving, lack of sociality, customized products, delivery service as well as privacy and security, have encouraged both consumers and businesses in online shopping as it makes everyday purchases much cheaper and simpler (Swinyard \& Smith, 2003; To, Liao \& Lin, 2007). Given the fierce competition of the apparel e-commerce market, online retailers must realize the importance of setting up high-quality websites. High-quality websites put a high emphasis on its functionality (information and systems quality) and systems quality in order to satisfy consumers' expectations (Saha \& Zhao, 2005). Carlson \& O'Cass (2010) also mentioned that the success of an online business depends on the collaborative efforts of both e-retailers and the extra-role participation of the e-shoppers. As satisfied customer possesses high potential in promoting the existing business, the advertising expenses will then be reduced (Ho\& Chew, 2012). Hence, working on these customers' potential will heavily benefit online businesses. Therefore, this research is aimed to study the influence of website quality as the antecedents of e-satisfaction on e-loyalty that would eventually lead to e-Customer Citizenship Behavior of online shopping of apparels. The contributions of this study would be of interest to online retailers as this research will provide an understanding of consumer insights, allowing the retailers to make necessary adjustments in fulfilling the customers' needs and wants while competing with each other in this competitive business nature.

\section{Literature Review}

Website Quality: Information Quality, Service Quality and Systems Quality: According to Udo, Bagchi \& Kirs (2010), website quality refers to the overall perceived quality of a website that not only shapes customers' initial impression but also influences customers' level of satisfaction and loyalty towards the website. Previous studies have indicated that the e-commerce success is more likely to happen when the website provides the highest level of quality among its competitors. Without a unified view, it would be difficult to study the success of website quality given the numerous factors (Hwang, Preiser-Houy \& Rong, 2012). Therefore, this research adopts DeLone and McLean's IS Success model which proposes Information Quality, System Quality and Service Quality as the three dimensions that would lead to ecommerce success (Petter, DeLone \& McLean, 2013). According to Schaupp (2009), information quality refers to the measurement of satisfaction level over the information content provided by an online shopping website. Compared to the traditional brick-and-mortar apparel stores, the greatest advantage of online shopping for the consumers would be the capacity to receive information that are useful, accurate and up-to-date which are relevant to their purchasing intention (Bharati \& Chaudhury, 2004). Therefore, 
providing such information is essential to Internet retailers, as online customers tend to shop frequently for convenience and search for products (Kuan Bock, \& Vathanophas, 2008). This research uses four of Doll \& Torkzadeh's (1988) five dimensions End-User Computing Satisfaction measure that corresponds to information quality - accuracy, content, format and timeliness. These dimensions were adopted given the preference of other researchers in literature to the said dimensions (Chin and Lee, 2000). Several studies have found a strong and positive relationship between information quality and satisfaction (Janda, Trocchia \& Gwinner, 2002; Szymanski \& Hise, 2002; Yang, 2007) However, given that information quality has no effect on satisfaction in virtual online community context by Chen, Chen \& Farn (2010), it can be proposed that the result of information quality would not result in similar satisfaction level in all online settings. Therefore, it can be hypothesized that information quality has a significant relationship towards e-satisfaction in an online apparel retailing.

$\mathrm{H}_{1 \mathrm{a}}$ : Information quality has a positive influence on e-satisfaction of online apparel shopping in Malaysia.

Service quality refers to the measurement of satisfaction with the service level provided by an online shopping website (Ahn Ryu \& Han, 2007). Service quality is predominantly important in Internet businesses, as online shopping does not require face-to-face contact (Ahn et al., 2007). This situation makes e-service quality crucial given that it only takes one click for the customer to switch to another website compared to the traditional website. Therefore, the expectation of customers in an online retail is much higher and harder to reach than in a traditional retail. In order to maintain customers, online retailers must be prepared to respond to the variety of customer demands such as order changes, cancellations, returns/refunds and quick delivery (Lin, 2007). Based on SERVQUAL, an instrument created by Parasuraman, Zeithaml \& Berry (1985) to measure consumer's expectation and service perception, five service quality dimensions are identified - tangibles, reliability, responsiveness, assurance and empathy. These dimensions of service quality are found to have a strong determinant of satisfaction for online stores and retailers (Wolfinbarger \& Gilly, 2003). There are several established studies which confirm that a higher level of service quality tends to increase the level of satisfaction (Chang and Wang, 2011; Deng, Lu, Wei, \& Zhang, 2010). Thus, it can be hypothesized that there is a relationship between service quality and customer satisfaction.

$\mathrm{H}_{1 \mathrm{~b}}$ : Service quality has a positive influence on e-satisfaction of online apparel shopping in Malaysia.

System quality refers to the measurement of satisfaction level over the functional and the technical aspects of an online shopping website (Ahn et al., 2007; Schaupp et al., 2009). Brown and Jayakody (2008) as well as Rai et al., (2002) had mentioned in their research that consumer's intention to purchase via the Internet is heavily influenced by the trustworthiness and ease of use of the shopping system. In this research, consumer's purchasing activities is supported by navigation, ease of accessibility, response time (Palmer, 2002; Schaupp et al., 2009) and security (Doll et al., 2004; Rai et al., 2002) as the main dimensions of system quality (Schaupp et al., 2009). Previous studies by Seddon (1997) and Lin, Wu and Chang (2010) positively relate system quality with satisfaction. Brown and Jayakody (2009) have also indicated the positive relationship between system quality and user satisfaction. The relationship between system quality and satisfaction is argued by Yang (2007) that mentions the inclination of consumers towards information quality and service quality than system quality. Given the difference between the relationship of system quality and online satisfaction, it can be hypothesized that system quality has a relationship towards e-satisfaction.

$\mathrm{H}_{1 c}$ : System quality has a positive influence on e-satisfaction of online apparel shopping in Malaysia.

Expectancy-Disconfirmation Theory and Social Exchange Theory: Drawing on the theories of consumer satisfaction, Oliver (1980) proposed the Expectancy-Disconfirmation paradigm, which measures the difference between expectation and perceived experience. This difference leads to either confirmation or disconfirmation (Bhattacherjee \& Premkumar, 2004). According to Yen and Lu (2008), customer's disconfirmation is positively related to their satisfaction, and this satisfaction will eventually lead towards loyalty behavior. Nevertheless, Expectancy-Disconfirmation Theory has been marked as the best theory in understanding consumers' satisfaction in the e-commerce context (Bhattacherjee \& Premkumar, 2004; Chih et al., 2012). Therefore, this theory can clearly be used to explain the relationship between website dimensions such as information quality, service quality and system quality towards esatisfaction. Social Exchange Theory (SET) explains the situation when individuals feel obligated to reciprocate to those who benefit them (Blau, 1964). In this research, consumers are most likely to develop a relationship with online retailers that they perceive to have invested resources in meeting their needs. SET provides a theoretical support for the link between customer satisfaction, customer loyalty, and customer citizenship behavior. On the other hand, it is implied that the social exchange relationship 
between organizations and customers is straightforward, as customers who are satisfied with the quality and performance of the e-retailer's service would go beyond the usual to repay the favor by voluntarily engaging in extra-role behavior such as helping behavior and positive recommendation (Anaza \& Zhao, 2013; Groth, 2005).

E-satisfaction, E-loyalty and E-Customer Citizenship Behavior: E-satisfaction was defined by Anderson \& Srinivasan (2003) as "the contentment of the customer with respect to his or her prior purchasing experience with a given electronic commerce firm". E-satisfaction would increase when the experience of the online service exceeds consumer's expectation on online shopping. E-satisfaction is deemed critical in Internet environment because if the customers are unsatisfied with the high-quality products or services that they have demanded, they will switch to another site with just a click (Kadir, Rahmani \& Masinaei, 2011). E-loyalty has been built on the definition of traditional consumer loyalty, where it is defined as customer's favorable attitude towards an electronic business resulting in repurchase behavior (Anderson \& Srinivasan, 2003). Cyr, Head and Ivanov (2009) previously has defined e-loyalty as the intention to revisit a website that might result in repeat purchase behavior.

E-Customer Citizenship Behavior (E-CCB) is defined as the voluntary and discretionary actions shown by online shoppers in an online service environment to ease the purchase, delivery and consumption of the e-services, while at the same time helping the firm service success (Groth, 2005). It is also considered to be the extension of consumer loyalty, as it measures other behavior of customers rather than just consumer loyalty. E-CCB is consist of three primary concepts: service firm facilitation, recommendation and helping behavior (Anaza \& Zhao, 2013; Bove et al., 2009; Groth, 2005). Given the importance of esatisfaction and e-loyalty to an online retail, it has been suggested that these positive behaviors of wordof-mouth, recommendation and helping behavior can foster the intention to revisit the shopping website (Flavián, Guinalíu \& Gurrea, 2006; Srinivasan, Anderson \& Ponnavolu, 2002). In general, customer citizenship behavior had obtained recognition from both scholars and retailers given its importance to the retail industry (Groth, 2005; Rosenbaum \& Massiah, 2007). According to Shahsavari \& Faryabi (2013), citizen customers will improve the performance and profitability of the business by repurchasing, providing feedback, recommending the retailer, as well as attracting new customers.

Several studies have established the importance of e-satisfaction on e-loyalty and e-customer citizenship behavior, considering that a satisfied customer is less likely to look for other alternatives as well as engage in supportive actions that reflect citizenship behaviors (Eid, 2007; Hsu, Wu \& Chen, 2012; Ltifli \& Gharbi 2012).However, Bettencourt (1997) found satisfaction to have a direct negative relationship with customer voice behaviors such as participation. Based on his perspective, satisfied customers are unlikely to help the e-retailers, as there are fewer reasons and opportunities to express on how to improve the retailers' service. Therefore, there is clearly a gap to look into leading to the hypothesis formation of a relationship between e-satisfaction and e-loyalty, as well as between e-satisfaction and e-customer citizenship behavior.

$\mathrm{H}_{2}$ : There is a relationship between e-satisfaction and e-loyalty of online apparel shopping in Malaysia

$\mathrm{H}_{3}$ : There is a relationship between e-satisfaction and e-customer citizenship behavior of online apparel shopping in Malaysia.

Similar to e-satisfaction, maintaining e-loyalty is hard due to the surrounding competitions. Several studies have shown that customer loyalty impacts customer organization citizenship behavior (Bove et al., 2009). Moreover, Bettencourt (1997) has listed loyalty as one of the three dimensions of customer citizenship behavior. Furthermore, findings by Macintosh (2002) have implied that customers of strong interpersonal relationship towards a retailer will exhibit dedication of extra role behaviors, such as cooperation and enhancement. However, the same cannot be concluded for e-shoppers in an online setting (Anaza \& Zhao, 2013). Therefore, it can be proposed that there is a relationship between e-loyalty and ecustomer citizenship behavior.

$\mathrm{H}_{4}$ : There is a relationship between e-loyalty and e-customer citizenship behavior of online apparel shopping in Malaysia.

Based on the literature presented, the research framework is presented in Figure 1. The framework uses the combination of DeLone and McLean's model for Information System Success with Anaza \& Zhao's (2013) framework. 
Figure 1: Research Framework

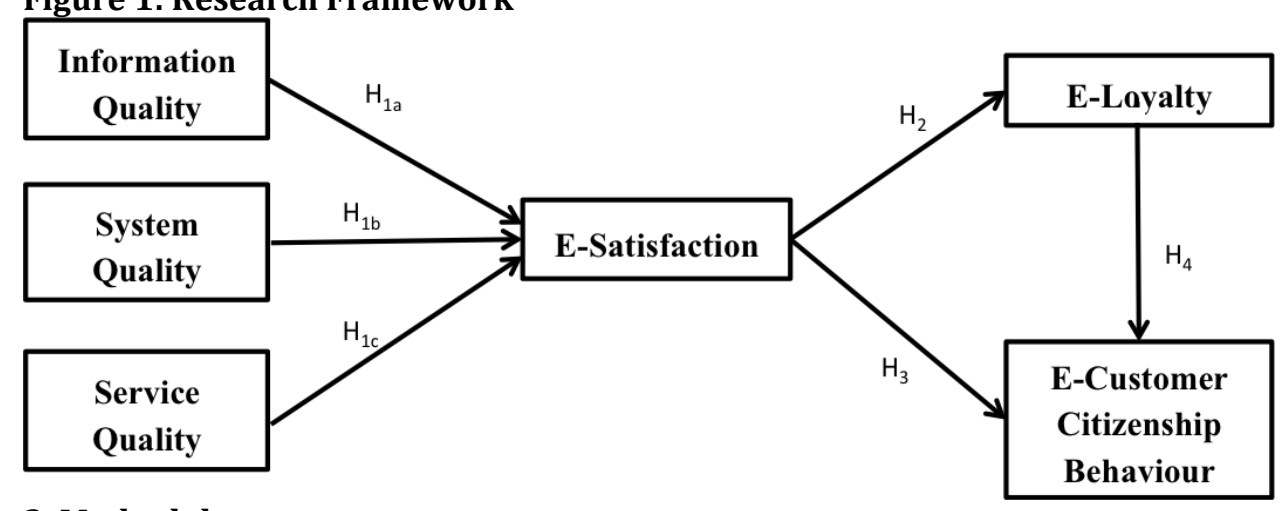

\section{Methodology}

Convenience sampling was the chosen sampling method for this research to provide convenience for the researcher. Due to the unknown number of online shoppers in Malaysia for apparel, Krejcie \& Morgan's (1970) table for determining sample size was used to collect a total of 385 respondents from the age range of 18-37. Looking at the age range, these respondents would mainly fall under Generation Y, which is perceived by Kotler \& Keller (2011) to be socially-conscious and information-wised as they were exposed to the use and development of technology since birth. The questionnaires were divided into parts, which include general questions, independent variables such as information quality, service quality and system quality, dependent variables of e-satisfaction, e-loyalty and e-customer citizenship behaviour, as well as demographic information. All questionnaires except the general information and the demographic variables were measured based on 5-point Likert scale, with $1=$ strongly disagree until $5=$ strongly agree. The research questions were adopted from various sources as shown in Table 1.

\section{Table 1: Questionnaire Sources\& Cronbach's Alpha}

\begin{tabular}{llll}
\hline Variable & Source & No of items & Cronbach's Alpha \\
\hline Information Quality & Barnes \& Vidgen (2002) & 4 & 0.868 \\
Service Quality & Wolfinbarger \& Gilly (2003) & 5 & 0.853 \\
System Quality & Wolfinbarger \& Gilly (2003) & 5 & 0.880 \\
E-Loyalty & Anderson \& Srinivasan (2003) & 5 & 0.924 \\
E-Satisfaction & Anderson \& Srinivasan (2003) & 5 & 0.912 \\
E-CCB & Groth (2005) & 5 & 0.888 \\
\hline
\end{tabular}

\section{Results and Findings}

Bivariate correlation result shows that all Information Quality, Service Quality and Systems Quality have a substantial relationship and are moderately correlated with e-satisfaction (Pearson $r$ ranges from 0.628 to 0.0 .671 ), $p$ value $0.000<0.01$ ). E-satisfaction is strongly and positively correlated with loyalty and ecustomer citizenship behavior (Pearson $r$ ranges from 0.727 to 0.769 ). The multiple regression analysis for hypothesis $1 \mathrm{a}, 1 \mathrm{~b}$ and $1 \mathrm{c}$, resulted in an overall coefficient $\mathrm{F}$ value of 132.212 ( $\mathrm{p}$-value $0.000<0.01$ ), implies that changes in at least one of the variables of the study have a significant effect in e-satisfaction. The adjusted $\mathrm{R}$ square, which is 0.506 , indicated that the model represents $50.6 \%$ of the total variable. The results suggest that information quality $(P=0.000, \beta=0.214, B=0.227, T=3.614)$, service quality $(P=0.002, \beta=0.193, B=0.196, T=3.048)$ and system quality $(P=0.000, \beta=0.375, B=0.360, T=6.583)$ have significant effect on consumer's e-satisfaction level ( $\mathrm{p}$-value $<0.01$ ). The model specification of the beta equation is presented below. With the figures obtained from multiple regression analysis, this equation measures the satisfaction level in relation to information quality, service quality and system quality.

\section{E-Satisfaction $=\mathrm{f}($ Information quality, Service quality, System quality $)$}

$$
\mathrm{S}=1.000+0.227 \mathrm{IQ}+0.196 \mathrm{SQ}+0.360 \mathrm{SYQ}
$$

For the result of multiple regression for hypothesis 2 , the overall coefficient was found as $\mathrm{R}^{2}=0.559$, Adj $\mathrm{R}^{2}=0.557, \mathrm{~F}=484.578$ ( $\mathrm{p}$-value $0.000<0.01$ ). Therefore, the result suggests that e-satisfaction $(\mathrm{P}=0.000$, $\beta=0.747, B=0.904, T=22.013$ ) has a significant impact on e-loyalty in an online apparel setting. The beta 
equation is presented below, where the equation measures the loyalty level in relation to the change in satisfaction level.

$$
\begin{array}{r}
\text { E-Loyalty }=\mathrm{f}(\text { E-Satisfaction }) \\
\mathrm{L}=0.198+0.904 \mathrm{~S}
\end{array}
$$

For the result of multiple regression for hypothesis 2 and 3, the overall coefficient was found as $\mathrm{R}^{2}=0.644$, Adj $\mathrm{R}^{2}=0.642, \mathrm{~F}=345.188$ ( $\mathrm{p}$-value $0.000<0.01$ ). Hence, the result proposes that e-satisfaction $(\mathrm{P}=0.000$, $\beta=0.345, B=0.353, T=7.512)$ and e-loyalty $(P=0.000, \beta=0.511, B=0.432, T=11.115)$ positively impact $e-$ customer citizenship behavior. The beta equation is presented below, where the equation measures the ecustomer citizenship behavior in relation to the change in e-satisfaction level and e-loyalty level.

E-Customer Citizenship Behavior = $\mathrm{f}($ E-Satisfaction, E-Loyalty)

C.C. $=0.844+0.353 \mathrm{~S}+0.432 \mathrm{I}$

Discussion: The findings of this study have reinforced DeLone \& McLean's model for Information System Success. The quality of a website from the perspective of information, service and systems are indeed essential to satisfy an e-customer. The significant relationship between information quality and esatisfaction supports the study of Lin et al. (2011), where in order to satisfy customer's information need, e-retailers must provide accurate, complete, formatted and up-to-date information on their websites. The relationship between system quality and e-satisfaction is also proven to have a positively correlated and strong relationship with e-satisfaction. This finding, however, contradicts the findings of Schaupp et al. (2009), which state that system quality has an insignificant relationship with customer satisfaction. According to Yang (2007), the main concerns of online shopping leans towards information quality and service quality as the technology advances, given consumers no longer bother about the easy access to using the system. On the other hand, the finding of this research has established a positive relationship between system quality and e-satisfaction. These results are further supported by previous researches, which indicated the similar relationship between system quality and satisfaction (Lin et al., 2011; Brown \& Jayakody, 2008). Meanwhile, Lee \& Kozar (2006) regards system quality to be the most important factor in online commerce. Not only that, it was concluded that respondents placed high importance on the security of the online shopping system, given that they still feel insecure about providing their financial information based on the findings of this research.

Further findings have proved the applicability of the Expectancy-Disconfirmation Theory and SocialExchange Theory in the context of online shopping. E-satisfaction has always been considered as a natural antecedent of e-loyalty [Anderson \& Srinivasan, 2003; Szymanski \& Hise, 2000]. Consumers who are satisfied tend to stay loyal to the online retailer by repurchasing and spreading positive word-of-mouth, as well as consider the retailer to be their first choice when they tend to make any purchase (Selnes, 1993). However, although e-satisfaction is likely to lead towards e-loyalty based on this research, other researchers would not assume that consumer satisfaction would always lead towards loyalty due to the risk and fear of change (Barnes\& Vidgen, 2002). Despite that, findings of this research is further strengthened by Uzun \& Poturak (2014), as they mentioned that customers with good online shopping experience from the website are more likely to be satisfied with the products and service, and in return tend to purchase more from the website, making them loyal to the online retail business.

The Social Exchange Theory posits that consumers tend to reciprocate extra-role behaviors such as helping other customers when consumers themselves feel satisfied with the e-commerce website quality (Chen, Chen \& Farn, 2010). Similarly, Morgan \& Hunt (1999) claimed that higher assessment reflects the better benefits provided by the company and thus, creating a likelihood for customers to perceive a social-exchange relationship. These ways of motivation process were confirmed further with Groth (2005) as he stated that customer citizenship behavior are strongly predicted by customer satisfaction, similar to organization citizenship behavior where employee satisfaction leads to a better extent of extrarole behaviors. Moreover, the findings between e-satisfaction and e-customer citizenship behavior were similar to Anaza \& Zhao (2013), where e-satisfaction is found significant to all three behaviors of ecustomer citizenship behavior: recommendation, helping behavior and service firm facilitation. More importantly, this study has empirically proved the capability of customers to extend their voluntary and invisible hand to the organization when they have developed e-loyalty towards the online shopping website. Loyalty and commitment were found to be the key factors leading to customer citizenship 
behavior (Shahsavari \& Faryabi, 2013). Similarly, another research by Yi \& Gong (2009) concluded that retailer's positive performance establishes customer citizenship behavior while retailer's negative performance establishes customers' dysfunctional behavior. Likewise, research by Anaza \& Zhao (2013) indicated that e-shoppers' loyalty would influence two citizenship behaviors, such as recommendation and helping behavior. Therefore, given the contribution of e-customer citizenship behavior to firm's profitability, managers must consider investing into loyalty-building programs, as it can be effective on customers' citizenship behavior.

\section{Conclusion, Limitations \& Recommendations}

It is crucial for online retailers to recognize the website as the first point of contact between customers and retailers in an online setting. Therefore, it is essential to recognize the importance of the website quality, such as information quality, service quality, and system quality, as it leads to user satisfaction and its extended behaviors. It is essential to know that when consumers are satisfied with the website quality, they are more likely to be loyal and to exhibit extra-role behavior such as recommending the business to other people, filling-out survey forms and helping other consumers in their purchase decisions. With the discovery of positive relationship between satisfaction and loyalty on e-customer citizenship behavior, online retailers can consider commitment and loyalty programs to be established in their services in order to improve customer collaboration in terms of helping the online retailer. Thus, online retailers must take advantage of this research in creating or modifying their websites and services. The incorporation of these aspects will eventually provide a competitive advantage as well as cost-reduction to the online retailer's marketing activities.

As with most studies, there are some limitations in this research which need to be accounted for. First of all, this study considered online clothing stores as the scope of its research and therefore there is no guarantee that the results could apply to other online marketplaces such as online bookstores, online travel agencies, among others. Future researchers could also consider performing similar research on other marketplaces, as it could generate different findings. Secondly, this research is also limited in terms of age. Older-aged consumers were not considered for this study, keeping in mind that older consumers are less likely to shop online compared to Generation Y due to their lack of technology enthusiasm. However, future studies would differ, and researchers could focus on older consumers, as their behavior would change in the coming years. Lastly, this research relies on respondent's self-reported data o study the impact of website quality dimensions as antecedents of e-satisfaction on e-loyalty and e-customer citizenship behavior. Although this method seemed appropriate for its research scope of online shopping in Malaysia, given that the questionnaire measures both expectation and performance, respondents might interpret and respond differently towards the rating scale. Therefore, future researches could consider mixed method approach, where both qualitative and quantitative methods are used in obtaining data.

\section{References}

Ahn, T., Ryu, S. \& Han, I. (2007). The impact of Web quality and playfulness on user acceptance of online retailing. Information \& Management, 44(3), 263-275. Available at: http://linkinghub.elsevier.com/retrieve/pii/S0378720607000225 [Accessed September 9, 2014].

Anaza, N. A. \& Zhao, J. (2013). Encounter-based antecedents of e-customer citizenship behaviors. Journal of Services Marketing, 27(2), 130-140. Available at: http://www.emeraldinsight.com/ 10.1108/08876041311309252 [Accessed July 9, 2014].

Anderson, R. E. \& Srinivasan, S. S. (2003). E-satisfaction and e-loyalty: A contingency framework. Psychology and Marketing, 20(2), 123-138. Available at: http://doi.wiley.com/10.1002/mar.10063 [Accessed March 19, 2014].

Barnes, S. J. \& Vidgen, R. T. (2002). An Integrative Approach to the Assessment of E-Commerce Quality. Journal of Electronic Commerce Research, 3(3), 114-127.

Bettencourt, L. A. (1997). Customer Voluntary Performance : Partners In Service -Delivery Customers As. Journal of Retailing, 73(3), 383-406.

Bharati, P. \& Chaudhury, A. (2004). An empirical investigation of decision-making satisfaction in webbased decision support systems. Decision Support Systems, 37(2), 187-197. Available at: http://linkinghub.elsevier.com/retrieve/pii/S016792360300006X [Accessed August 14, 2014]. 
Bhattacherjee, A. \& Premkumar, G. (2004). Understanding Changes in Belief and Attitude toward Information Technology Usage: A Theoretical Model and Longitudinal Test. MIS Quarterly, 28(2), 229-254.

Blau, P. M. (1964). Exchange and Power in Social Life, New York, NY: John Wiley \& Sons.

Bove, L. L., Pervan, S. J., Beatty, S. E. \& Shiu, E. (2009). Service worker role in encouraging customer organizational citizenship behaviors. Journal of Business Research, 62(7), 698-705. Available at: http://linkinghub.elsevier.com/retrieve/pii/S014829630800177X [Accessed September 2, 2014].

Brown, I. \& Jayakody, R. (2008). B2C e-Commerce Success : a Test and Validation of a Revised Conceptual Model. Electronic Journal Information Systems Evaluation, 11(3), 167-184.

Brown, I. \& Jayakody, R. (2009). B2C e-commerce success: A test and validation of a revised conceptual model. The Electronic Journal Information Systems Evaluation, 12(2), 129-148.

Carlson, J. \& O'Cass, A. (2010). Exploring the relationships between e-service quality, satisfaction, attitudes and behaviours in content-driven e-service web sites. Journal of Services Marketing, 24(2), 112-127. Available at: http://www.emeraldinsight.com/10.1108/08876041011031091 [Accessed July 25, 2014].

Chang, H. H. \& Wang, H. W. (2011). he moderating effect of customer perceived value on online shopping behaviour. Online Information Review, 35(3), 333-359.

Chen, M., Chen, C. \& Farn, C. (2010). Exploring Determinants of Citizenship Behavior on Virtual Communities of Consumption: The Perspective of Social Exchange Theory. International Journal of Electronic Business Management, 8(3), 195-205.

Chih, W. H., Wang, K. Y., Hsu, L. C. \& Cheng, I. S. (2012). From disconfirmation to switching: an empirical investigation of switching intentions after service failure and recovery. The Service Industries Journal, 32(8), 1305-1321.

Chin, W. W. \& Lee, M. K. (2000). Proposed Model and Measurement Instrument for the Formation of IS Satisfaction: The Case of End-User Computing Satisfaction. In Twenty-First International Conference on Information Systems. Brisbane, Australia, 553-563.

Cyr, D., Head, M. \& Ivanov, A. (2009). Perceived interactivity leading to e-loyalty: Development of a model for cognitive-affective user responses. International Journal of Human-Computer Studies, $67(10)$, 850-869. Available at: http://linkinghub.elsevier.com/retrieve/pii/S1071581909000925 [Accessed April 26, 2014].

Deng, Z., Lu, Y., Wei, K. K. \& Zhang, J. (2010). Understanding customer satisfaction and loyalty: an empirical study of mobile instantmessages in China. International Journal of Information Management, 30(4), 316-33.

Doll, W. J., Deng, X., Ragunathan, T. S., Torkzadeh, G. \& Xia, W. (2004). The meaning and measurement of user satisfaction: A multigroup invariance analysis of the end-user computing satisfaction instrument. Journal of Management Information Systems, 21(1), 227-262.

Doll, W. J. \& Torkzadeh, G. (1988). The Measurement of End-User Computing Satisfaction. MIS Quarterly, $12(2), 259-274$.

Eid, M. I. (2007). Determinants of E-Commerce customer satisfaction, trust and loyalty in Saudi Arabia. Journal of Electronic Commerce Research, 12(1), 78-93.

Euromonitor International. (2014). Internet Retailing in Malaysia. Passport. Available at: http://www.portal.euromonitor.com.ezproxy.lancs.ac.uk/Portal/Pages/Search/SearchResultsL ist.aspx [Accessed April 25, 2014].

Euromonitor International. (2013). Retailing in Malaysia. Passport. Available at: http://www.portal.euromonitor.com.ezproxy.lancs.ac.uk/Portal/Pages/Search/SearchResultsL ist.aspx [Accessed April 11, 2014].

Flavián, C., Guinalíu, M. \& Gurrea, R. (2006). The influence of familiarity and usability on loyalty to online journalistic services: The role of user experience. Journal of Retailing and Consumer Services, 13(5), 363-375. Available at: http://linkinghub.elsevier.com/retrieve/pii/S0969698905000913 [Accessed September 11, 2014].

Groth, M. (2005). Customers as Good Soldiers: Examining Citizenship Behaviors in Internet Service Deliveries. Journal of Management, 31(1), 7-27. Available at: http://jom.sagepub.com /cgi/doi/10.1177/0149206304271375 [Accessed September 2, 2014].

Ho, J. S. \& Chew, K. (2012). Website Personality, Website Quality and Customer Citizenship Behaviour Among Online Shoppers. In 1st Annual Young Researchers International Conference and Exhibition. PWTC KL. 
Hsu, C. L., Wu, C. C. \& Chen, M. C. (2012). An empirical analysis of the antecedents of e-satisfaction and eloyalty: focusing on the role of flow and its antecedents. Information Systems and e-Business Management, 11(2), 287-311. Available at: http://link.springer.com/10. 1007/s10257-0120194-8 [Accessed March 19, 2014].

Hwang, D., Preiser-Houy, L. \& Rong, A. S. (2012). A Comprehensive Framework for Online Store Functionalities. Issues in Information Systems, 13(2), 336-345.

Janda, S., Trocchia, P. J. \& Gwinner, K. P. (2002). Consumer perceptions of Internet retail service quality. International Journal of Service Industry Management, 13(5), 412-431.

Kadir, H. A., Rahmani, N. \& Masinaei, R. (2011). Impacts of service quality on customer satisfaction: Study of Online banking and ATM services in Malaysia. International Journal of Trade, Economics and Finance, 2(1), 1-9. Available at: http://www.ijtef.org/show-29-323-1.html.

Kotler, P. \& Keller, K. (2011). Marketing Management 14th Edition, Prentice Hall. Available at: http://books.google.com/books? id=Y009AwAAQBAJ\&pgis=1 [Accessed April 19, 2014].

Krejcie, R. V. \& Morgan, D. W. (1970). Determining Sample Size For Research Activities. Educational and Psychological Measurement, 30, 607-610.

Kuan, H. H., Bock, G. W. \& Vathanophas, V. (2008). Comparing the effects of website quality on customer initial purchase and continued purchase at e-commerce websites. Behaviour \& Information Technology, 27(1), 3-16. Available at: http://www.informaworld.com/openurl?genre=article\&doi=10.1080/01449290600801959\& magic $=$ crossref||D404A21C5BB053405B1A640AFFD44AE3 [Accessed September 17, 2014].

Lee, Y. \& Kozar, K. A. (2006). Investigating the effect of website quality on e-business success: An analytic hierarchy process (AHP) approach. Decision Support Systems, 42(3), 1383-1401. Available at: http://linkinghub.elsevier.com /retrieve/pii/S016792360500165X [Accessed November 2, 2014].

Lin, C. C., Wu, H. Y. \& Chang, Y. F. (2011). The critical factors impact on online customer satisfaction. Procedia Computer Science, 3, 276-281. Available at: http://linkinghub.else vier.com/retrieve/pii/S1877050910004229 [Accessed August 18, 2014].

Lin, H. F. (2007). The Impact of Website Quality Dimensions on Customer Satisfaction in the B2C Ecommerce Context. Total Quality Management \& Business Excellence, 18(4), 363-378. Available at: http://www.tandfonline.com /doi/abs/10.1080/14783360701231302 [Accessed November 2, 2014].

Ltifli, M. \& Gharbi, J. E. (2012). E-satisfaction and e-loyalty of consumers shopping online. Journal of Internet Banking and Commerce, 17(1), 1-20.

Macintosh, G. (2002). Perceived risk and outcome differences in multi-level service relationships. Journal of Services Marketing, 16(2), 143-157.

Morgan, R. M. \& Hunt, S. (1999). Relationship-Based Competitive Advantage: The Role of Relationship Marketing in Marketing Strategy. Journal of Business Research, 46, 281-290.

Oliver, R. L. (1980). A Cognitive Model of the Antecedents of Satisfaction Decisions. Journal of Marketing Research, 17(4), 46-49.

Palmer, J. (2002). Web site usability, design, and performance metrics. Information Systems Research, 12(2), 151-167.

Parasuraman, A., Zeithmal, V. A. \& Berry, L. (1985). A Conceptual Model of Service Quality and Its Implications for Future Research. Journal of Marketing, 2, 41-50.

Petter, S., DeLone, W. \& McLean, E. R. (2013). Information Systems Success: The Quest for the Independent Variables. Journal of Management Information Systems, 29(4), 7-62.

Rai, A., Lang, S. S. \& Welker, R. B. (2002). Assessing the validity of IS success models: An empirical test and theoretical analysis. Information Systems Research, 13(1), 50-69.

Rosenbaum, M. S. \& Massiah, C. A. (2007). When customers receive support from other customers: Exploring the influence of intercustomer social support on customer voluntary performance. Journal of Service Research, 9, 257-270.

Saha, P. \& Zhao, Y. (2005). Relationship between Online Service Quality and Customer Satisfaction: A Study in Internet Banking. Lulea University of Technology.

Schaupp, L. C., Belanger, F. \& Fan, W. (2009). Examining the success of websites beyond e-commerce : an extension of the is success model. Journal of Computer Information System, 49(4), 42-52.

Seddon, P. B. (1997). A Respecification and Extension of the DeLone and McLean Model of IS Success. Information Systems Research, 8(3), 240-253.

Selnes, F. (1993). An examination of the effect of product performance on brand reputation,satisfaction and loyalty. European Journal of Marketing, 27(9), 19-35. 
Shahsavari, A. \& Faryabi, M. (2013). The Effect of Customer-Based Corporate Reputation on Customers ' Citizenship Behaviors in Banking Industry. Research Journal of Applied Sciences, Engineering and Technology, 6(20), 3746-3755.

Srinivasan, S. S., Anderson, R. \& Ponnavolu, K. (2002). Customer loyalty in e-commerce: an exploration of its antecedents and consequences. Journal of Retailing, 78(1), 41-50. Available at: http://www.sciencedirect.com/science/article/pii/S0022435901000653 [Accessed March 22, 2014].

Swinyard, W. R. \& Smith, S. M. (2003). Why people (don't) shop online: A lifestyle study of the internet consumer. Psychology and Marketing, 20(7), 567-597. Available at: http://doi.wiley.com/10.1002/mar.10087 [Accessed November 18, 2014].

Szymanski, D. M. \& Hise, R. T. (2000). E-satisfaction: an initial examination. Journal of Retailing, 76(3), 309-322. Available at: http://linkinghub. elsevier.com/retrieve/pii/S002243590000035X.

To, P. L., Liao, C. \& Lin, T. H. (2007). Shopping motivations on Internet: A study based on utilitarian and hedonic value. Technovation, 27(2), 774-787.

Udo, G. I., Bagchi, K. K. \& Kirs, P. I. (2010). An assessment of customers' e-service quality perception, satisfaction and intention. International Journal of Information Management, 30, 481-492.

Uzun, H. \& Poturak, M. (2014). Factors Affecting Online Shopping Behavior of Consumers. European Journal of Social and Human Sciences, 3(3), 163-170.

Wolfinbarger, M. \& Gilly, M. C. (2003). eTailQ: dimensionalizing, measuring and predicting etail quality. Journal of Retailing, 79(3), 183-198. Available at: http://linkinghub.elsevier.com/ retrieve/pii/S0022435903000344 [Accessed August 2, 2014].

Yang, H. (2007). Assessing the effects of e-quality and e-satisfaction on website loyalty. International Journal of Mathematics and Computers in Simulation, 1(3), 288-294.

Yen, C. H. \& Lu, H. P. (2008). Factors influencing online auction repurchase intention. Internet Research, 18(1), 7-25.

Yi, Y. \& Gong, T. (2009). An Integrated Model of Customer Social Exchange Relationship : The Moderating Role of Customer Experience. Service Industries Journal, 29(11), 1513-1528. 